\title{
Late presentation of severe gouty tophi affecting both hands
}

\author{
Caitlin Renouf
}

Renal Dept, South Tees Hospitals NHS Foundation Trust, Middlesbrough, UK

\section{Correspondence to}

Dr Caitlin Renouf;

c.renouf@nhs.net

Accepted 2 December 2021

Check for updates

(c) BMJ Publishing Group Limited 2022. No commercial re-use. See rights and permissions. Published by BMJ.

To cite: Renouf C. BMJ Case Rep 2022;15:e246818. doi:10.1136/bcr-2021246818

\section{DESCRIPTION}

This patient is an 85-year-old man who was admitted to hospital via diabetic foot clinic with a rash and worsening renal function. He had a nonblanching, palpable and purpuric rash on both legs extending up to his abdomen. He felt otherwise well and reported no other symptoms. His medical history included type 2 diabetes mellitus, moderate left ventricular systolic dysfunction, hypertension, paroxysmal atrial fibrillation, chronic kidney disease (CKD) stage 3 and dyslipidaemia. His regular medications included linagliptin, bisoprolol, simvastatin, warfarin, paracetamol and low-dose furosemide. He had no documented history of gout in primary or secondary care and no symptoms or signs of gout were documented in his admission clerking.

The patient was started on $30 \mathrm{mg}$ oral prednisolone once daily with a likely diagnosis of Henoch-Schönlein purpura. He received intravenous fluid therapy in the initial days of his admission and his acute kidney injury (AKI) resolved over the course of his 7 day inpatient stay. On day of discharge, a junior doctor, while taking blood samples, highlighted extensive gouty tophi affecting both of his hands (figure 1). He had not seen a rheumatologist and had never taken oral medication for gout. On further questioning, he clarified that none of his other joints had been previously affected by gouty arthritis. He had minimal alcohol intake. The patient used over-the-counter ibuprofen to alleviate severe pain that mainly affected him when doing the washing up or driving for long periods. On examination, there was no evidence of tophi elsewhere. A serum urate level added to his blood tests was raised at $832 \mu \mathrm{mol} / \mathrm{L}$ (normal range is $200-400 \mu \mathrm{mol} / \mathrm{L}$ ). Based on the clinical appearance of this patient's hands alongside the raised urate, we diagnosed gouty tophi, commenced $200 \mathrm{mg}$ allopurinol once daily and arranged follow-up in rheumatology clinic.

The large majority of patients with hyperuricaemia will remain asymptomatic; however, gout is a painful but treatable condition that can result from raised serum urate levels. Hyperuricaemia is caused by increased production and/or decreased excretion of uric acid. ${ }^{1}$ Gout can then present in the following clinical scenarios: asymptomatic hyperuricaemia, acute gout flares, intercritical phases or chronic tophaceous gout. The development of severe tophi with no history of previous gouty arthritis is rare but recognised in case reports. ${ }^{2} 3$ Non-steroidal anti-inflammatory drugs and colchicine can alleviate acutely painful inflammatory changes seen in early presentations of gout. ${ }^{45}$ Urate-lowering medications, namely xanthine oxidase inhibitor allopurinol, help prevent late presentations of

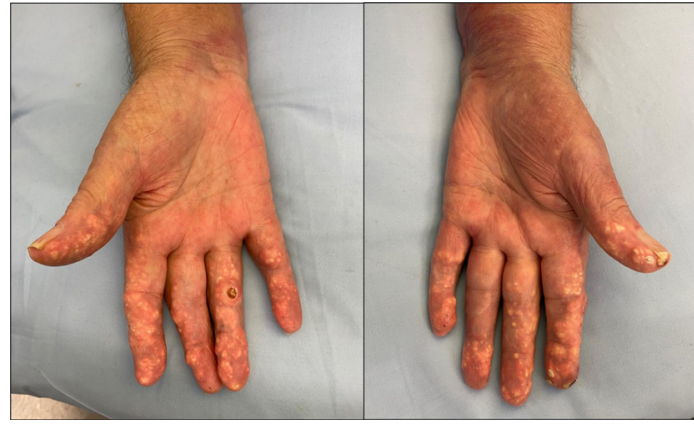

Figure 1 Severe gouty tophi affecting both hands, mainly seen on the palmar aspects of the patient's digits. Multiple skin breaks are seen where tophi have erupted and caused open sores appearing as punched-out lesions.

hyperuricaemia including chronic gouty tophi and kidney stones, ${ }^{6-8}$ such as the tophi seen in this patient.

There is debate about the exact impact and role of hyperuricaemia in AKI and CKD. However, evidence suggests that raised serum urate levels can cause or exacerbate AKI through systemic effects of raised serum urate and local tubular effects of uric acid in urine. ${ }^{489}$ In this case, the patient's significant hyperuricaemia and subsequent use of ibuprofen were previously unexplored factors that could have contributed to or exacerbated his AKI.

\section{Patient's perspective}

Nobody has ever taken this much notice of my hands before. I never knew anyone would find them interesting; they have been this way for so long now that I hardly notice them. I did not realise there was anything I could do about them.

\section{Learning points}

The development of gouty tophi without a prior history of gouty arthritis is a rare but recognised presentation of gout.

- Early prophylactic treatment with xanthine oxidase inhibitors can help prevent severe and painful chronic gouty tophi.

- Significant hyperuricaemia can have a role in development of acute kidney injury and chronic kidney disease. Physicians should consider the benefits of treatment to lower urate levels on kidney function. 
His hyperuricaemia may also contribute to the progression of his CKD.

Acknowledgements Thank you to Dr Thomas Adams for his support.

Contributors $C R$ was closely involved in the care of this patient and consented them for their involvement in this case report. CR wrote, edited and revised this manuscript.

Funding The authors have not declared a specific grant for this research from any funding agency in the public, commercial or not-for-profit sectors.

Competing interests None declared.

Patient consent for publication Consent obtained directly from patient(s).

Provenance and peer review Not commissioned; externally peer reviewed.

Case reports provide a valuable learning resource for the scientific community and can indicate areas of interest for future research. They should not be used in isolation to guide treatment choices or public health policy.
ORCID iD

Caitlin Renouf http://orcid.org/0000-0001-9926-8047

\section{REFERENCES}

1 George C, Minter DA. Hyperuricemia. StatPearls. 2021; Jan(2021). Available: www.ncbi. nlm.nih.gov/books/NBK459218/ [Accessed 3 Sep 2021].

2 Thissen CACB, Frank J, Lucker GPH. Tophi as first clinical sign of gout. Int J Dermatol 2008:47 Suppl 1:49-51.

3 Kumar P, Das A, Savant SS, et al. Gout nodulosis: report of a rare case and brief review. Dermatol Online J 2015;21:8.

4 Shin $\mathrm{DH}$. To treat or not to treat asymptomatic hyperuricemia in chronic kidney disease. Kidney Res Clin Pract 2019;38:257-9.

5 Dalbeth N, Choi HK, Joosten LAB, et al. Gout. Nat Rev Dis Primers 2019:5:69.

6 Ragab G, Elshahaly M, Bardin T. Gout: An old disease in new perspective - A review. J Adv Res 2017:8:495-511.

7 Chhana A, Dalbeth N. The gouty tophus: a review. Curr Rheumatol Rep 2015;17:19.

8 Angalla R, Mounir A, Driouich S, et al. Chronic tophaceous gout. QJM 2016;109:681-2.

9 Hahn K, Kanbay M, Lanaspa MA, et al. Serum uric acid and acute kidney injury: a mini review. J Adv Res 2017;8:529-36.

Copyright 2021 BMJ Publishing Group. All rights reserved. For permission to reuse any of this content visit

https://www.bmj.com/company/products-services/rights-and-licensing/permissions/

BMJ Case Report Fellows may re-use this article for personal use and teaching without any further permission.

Become a Fellow of BMJ Case Reports today and you can:

- Submit as many cases as you like

- Enjoy fast sympathetic peer review and rapid publication of accepted articles

- Access all the published articles

Re-use any of the published material for personal use and teaching without further permission

\section{Customer Service}

If you have any further queries about your subscription, please contact our customer services team on +44 (0) 2071111105 or via email at support@bmj.com.

Visit casereports.bmj.com for more articles like this and to become a Fellow 